\title{
Feeding Habits of Winter Flounder (Pleuronectes americanus) in a Habitat Exposed to Anthropogenic Disturbance
}

\author{
John K. Carlson ${ }^{1}$ \\ Southern Connecticut State University, Biology Department \\ 501 Crescent Street, New Haven, CT 06515, USA \\ Todd A. Randall \\ Biology Department, University of Mississippi \\ University, MS 38677, USA \\ Matthew E. Mroczka \\ Cedar Island Marine Research Laboratory \\ P. O. Box 181, Clinton, CT 06413, USA
}

\begin{abstract}
The feeding habits of the winter flounder (Pleuronectes americanus) were examined in a habitat subjected to chronic anthropogenic disturbance by organic and inorganic nutrient disposal and shipping activity. The macrobenthic community was numerically dominated by the types of polychaetes and amphipods found in a disturbed community. Little variability was found in the diets of 151 winter flounder (100-300 mm total length) in 4 size-classes. Combining all size-classes, winter flounder were found to feed on 18 different genera of macrobenthos. Amphipods and polychaetes dominated the diet. These groups provided from $12-25 \%$ of the diet by weight, $16-48 \%$ by number, and had index of relative importance values between 552 and 2 510. Major prey items were the amphipod, Ampelisca abdita and the polychaete, Streblospio benedicti. These diets were compared to those winter flounder captured in habitats where benthic assemblages were not exposed to human perturbation. Regardless of habitat, winter flounder fed on primarily the most abundant and active benthic species. This study supports the contention that winter flounder are in general, opportunistic feeders and usually feed on the most abundant and available prey source.
\end{abstract}

Key words: benthos, diet, disturbance, flounder, foraging

\section{Introduction}

The winter flounder (Pleuronectes americanus) is one of the most abundant demersal fishes of the Long Island Sound estuarine system and is an important commercial and recreational fish (Smith et al., 1989). Winter flounder feed primarily on benthic invertebrates (Klein-Mcphee, MS 1978) but variation in diet can occur between habitats (Pearcy, 1962; Richards, 1963; Frame, MS 1972; Tyler, 1972; Hacunda, 1981; Macdonald and Green, 1986; Keats, 1990) suggesting winter flounder are opportunistic feeders.

In many areas of Long Island Sound, the composition of the macrobenthic habitat has been altered by anthropogenic disturbances; including hypoxia, dredging, dredge-spoil dumping, shipping traffic and sewage disposal (Rhoads et al., 1978; Wolfe et al., 1991). In recent years, much attention has focused on how various types of anthropogenic disturbances affect the Long Island Sound estuary. Although Howell and Simpson (1994) studied the correlation between hypoxia and marine fish distribution and abundance, most research has largely been directed towards the effects contaminants have on various marine resources (Gronlund et al., 1991; Robertson et al., 1991). The consequence of anthropogenic disturbances on the feeding ecology of benthic feeding fishes are less known. Therefore, this information may be necessary for sound management of marine fisheries stocks (Becker and Chew, 1987).

Typically, macrobenthic invertebrate assemblages in habitats exposed to perturbations are

1 Correspondence and present address: Southeast Fisheries Science Center, National Marine Fisheries Service, NOAA 3500 Delwood Beach Road, Panama City, FL 32408,US 
dominated by opportunistic species char-acterized by small size, high fecundity rates, and ability to colonize the habitat rapidly (Pearson and Rosenberg, 1978; Rhoads et al., 1978; Warwick, 1986; McManus and Pauly, 1990). These characteristics allow these species to reach high population densities quickly (Levinton, 1982; Warwick, 1986) and may represent an enhanced forage base for some benthic feeding fishes.

How important are opportunistic benthic species to winter flounder? Since winter flounder are benthic invertebrate feeders, the high density and epifaunal distribution of these opportunists could make them an easily obtainable food source and could be selectively fed upon. To evaluate this suggestion, we examined the diets of winter flounder in a habitat exposed to chronic human perturbation. In particular, our objectives were: (1) describe the diet of different size-classes of winter flounder; (2) compare these diets with prey items potentially available in the benthic habitat; and (3) compare these diets of winter flounder to those captured in habitats where benthic assemblages are not exposed to human perturbation.

\section{Materials and Methods}

Trawl samples were made twice monthly to collect winter flounder along the eastern end of New Haven Harbor (Area 1) during September-November of 1989 and 1990. A $9.1 \mathrm{~m}$ otter trawl with $50.8 \mathrm{~mm}$ \#15 nylon mesh and a $38.1 \mathrm{~mm}$ mesh cod end was towed for 15 minutes along one transect line (Fig. 1).

Immediately after capture, winter flounder were measured (total length, $\mathrm{TL}$ in $\mathrm{mm}$ ) and divided into $50 \mathrm{~mm}$ size categories. Stomachs were removed by cutting at the esophagus and pyloric constriction. Stomachs were fixed at sea in $10 \%$ formalin. The contents were sorted in the laboratory and identified to the lowest possible taxon. Prey items were blot dried and the number of individuals and total weight of each prey type recorded. Portions of prey items were counted as remains unless an anterior end could be found. Total weight included shell weight for molluscs and crustaceans and test weight of echinoderms.

Prior to trawling, bottom salinity and temperature were measured with a YSI model 33 temperature-salinity-conductivity meter. Dissolved oxygen concentrations were determined using the azide modification of the Standard Winkler Titration Methods (Rand et al., 1975) and benthic samples were taken along the trawl transect (Fig. 1). Three random benthic samples were taken at one station along the trawl transect using a ponar grab which samples an area of $0.05 \mathrm{~m}^{2}$. Grab samples were washed through a $0.5 \mathrm{~mm}$ sieve, stained with rose

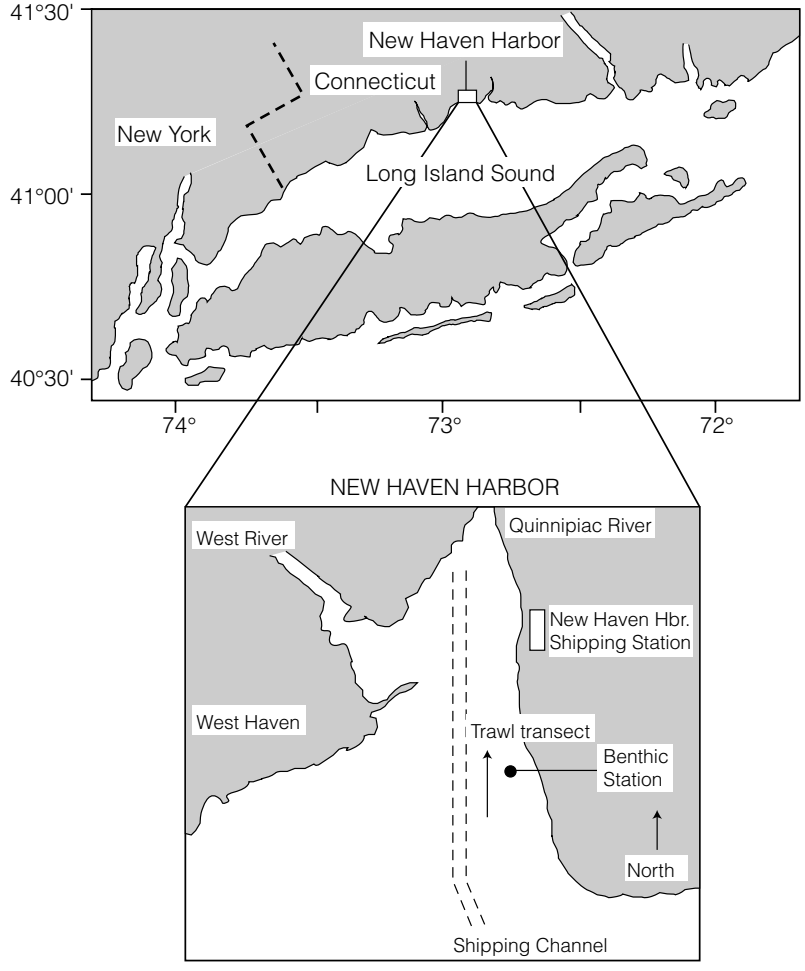

Fig. 1. Map of study area with the location of New Haven Harbor (Area 1) within Long Island Sound and location of trawl transect and benthic station within New Haven Harbor.

bengal and fixed in 10\% formalin. Grab samples were sorted in the laboratory and organisms identified to the lowest possible taxon. For analysis, replicate grab samples were pooled and summarized for each sampling year.

The contribution of different prey categories (i.e. taxa) to the diet was determined by three methods: (1) the wet weight of a prey category divided by wet weight of the total stomach contents; (2) the numerical abundance of individuals of a prey category divided by the total number of individual prey in the stomach; and (3) the frequency of occurrence of the number of stomachs in which a prey category occurred divided by the total number of stomachs examined.

To evaluate the importance of each prey item in the diet, an index of relative importance (IRI) developed by Pianka et al. (1971) and modified by Hacunda (1981) was used:

$$
\mid R I=(N+W) F
$$

where $N$ is the numerical percentage,

$W$ is the weight percentage, and

$F$ is the frequency of occurrence. 
Principal prey items were defined as those prey having an $|R|>100$ (Hacunda, 1981).

Differences in the diets between size-classes of winter flounder were examined. The numerical and weight percent contribution and $|R|$ of each principal prey item in the flounder diet from each size-class of winter flounder was ranked by its total contribution and compared using Kruskal-Wallis nonparametric procedures (Zar, 1984).

The selectivity of major prey items was tested using Shorigin's ratio of food selection (FR) as modified by Jacobs (1974) to correct for intrinsic asymmetry:

$$
F R=L O G_{10}\left(r_{i} / p_{i}\right)
$$

where; $F R$ is the forage index,

$r_{i}$ is percent contribution by number of prey $_{i}$ in the predator's diet, and

$p_{i}$ is the percent contribution by number of the same prey item in the benthos.

This value ranges from negative infinity to positive infinity with a positive value indicating preference or high accessibility and a negative value indicating avoidance or low accessibility. A value equal or close to 0 indicates random feeding.

To examine differences in the diets of winter flounder between habitats without human perturbation, the ranked values of number, weight and $|R|$ of principal prey found in the present study were compared using nonparametric procedures with those from winter flounder $(n=29)$ obtained at 2 sites during the same time period in Clinton Harbor, Clinton, Connecticut, USA (Area 2) by Mroczka (MS 1991) and Mroczka (unpublished data). The sites are located on intertidal and subtidal mud flats near the mouth of the Hammonassett River, Clinton, CT. Flounder were sampled using a 1-m beam trawl made of knotless $6.4 \mathrm{~mm}$ nylon mesh with one tickler chair and a $3.4 \mathrm{~m}$ shrimp trawl with $25.4 \mathrm{~mm}$ nylon mesh. Flounder were processed identical to methods described previously.

\section{Case Study}

New Haven Harbor is an polyhaline estuary located in south central Connecticut, approximately midway between New York City, New York, USA and Providence, Rhode Island, USA, on the northern shore of Long Island Sound (Fig. 1). The harbor is located at the mouth of the Quinnipiac River and is lined with estuarine embayment, near shore waters, intertidal flats, shellfish concentration areas and developed shore front. The harbor is composed of fine grain (silt-clay) sediments with a high organic content (Tubman, 1979). New Haven Harbor is a significant focus for commercial and industrial activity. The harbor receives an extremely high organic and contaminant load from municipal and industrial discharges as well as intense periods of shipping traffic by large commercial tankers and vessels (Tubman, 1979; Wolfe et al., 1991).

Clinton Harbor is located in Clinton, Connecticut, USA, which is centrally located along the Connecticut southern coastline on the Long Island Sound northern border. The harbor occupies approximately $1604 \mathrm{~km}^{2}$ and has a mean tidal range of $1.5 \mathrm{~m}$. Freshwater discharge into the study sites is from the Hammonassett River.

\section{Results}

\section{Physical Parameters}

The study site in New Haven Harbor (Area 1) exhibited typical estuarine abiotic characteristics throughout the study period. During both years, water temperatures were $11^{\circ}-20^{\circ} \mathrm{C}$ with warmer temperatures in September and cooler temperatures in November. Salinity averaged 19-21 ppt. Despite the high nutrient load to the harbor, dissolved oxygen levels generally exceeded $6.0 \mathrm{mg}$ per I and never fell below $4.0 \mathrm{mg}$ per I. Water temperature were $8^{\circ}-19^{\circ} \mathrm{C}$ from September-November and salinity averaged 13-19 ppt.

\section{Diet}

Overall, the diet of winter flounder $(n=151)$ collected in Area 1 was composed of 18 different genera from 5 major taxa (Table 1). Polychaetes and amphipods which dominated the diet, provided 12 and $26 \%$ of the diet respectively by weight, 32 and $48 \%$ by number and had $|R|$ values of 552 and 2510 . The 3 principal prey items were the amphipod Ampelisca abdita; the polychaete, Streblospio benedicti; and portions of Nassarius trivitattus, mainly the foot and operculum.

Winter flounder (100-300 mm TL) from Area 1 were divided into four $50 \mathrm{~mm}$ TL size-classes and examined for dietary components. Among sizeclasses, 5 principal prey items were determined: A. abdita, S. benedicti, oyster crab, Pinnixa sp.; mysid shrimp; Neomysis americana, and foot and opercular regions from N. trivitattus (Fig. 2). Ampelisca abdita and $S$. benedicti were the most important of principal prey comprising up to $77 \%$ of the diet. Although hydroids made up a portion of the diet by weight, the inability to discern individuals made counting impossible and thus they were not included in the dietary comparison. There was no significant difference in the number $(H=0.165$, $p \geq 0.05)$, weight $(H=2.31, p \geq 0.05)$, and the $|R|$ $(H=1.03, p \geq 0.05)$ of each principal prey item between 4 size-classes of winter flounder. 
TABLE 1. Diet of 151 winter flounder (size range $=100-300 \mathrm{~mm} \mathrm{TL}$ ) showing index of relative importance (IRI) of prey from Area 1, expressed in percentage weight, number and frequency of the total number of stomachs analyzed (45 stomachs empty). A value less than 0.05 is designated $(+)$.

\begin{tabular}{|c|c|c|c|c|}
\hline Taxon & Weight & Number & Frequency & $|\mathrm{R}|$ \\
\hline Mollusca (Total) & 17.25 & 17.21 & 13.87 & 478.00 \\
\hline Bivalve siphons & 1.04 & 0.20 & 2.64 & 3.27 \\
\hline Macoma balthica & 0.24 & 0.30 & 2.64 & 1.32 \\
\hline Nassarius trivittatus & 0.19 & + & 0.66 & 0.13 \\
\hline Gastropod foot & 15.77 & 16.69 & 8.58 & 278.00 \\
\hline Polychaeta (Total) & 12.22 & 31.72 & 12.57 & 552.00 \\
\hline Eteone heteropoda & + & 0.16 & 1.32 & 0.23 \\
\hline Leitoscoloplos robustus & 0.64 & 0.16 & 0.66 & 0.52 \\
\hline Nereis succinea & 1.50 & 0.24 & 2.07 & 3.44 \\
\hline Mediomastus ambiseta & + & 0.05 & 0.66 & 0.02 \\
\hline Streblospio benedicti & 7.10 & 31.11 & 3.31 & 124 \\
\hline Polychaeta remains & 2.92 & - & 4.92 & - \\
\hline Crustacea (Total) & 46.25 & 50.70 & 67.40 & 6486.0 \\
\hline Crustacean remains & 7.28 & - & 10.92 & - \\
\hline Cancer irroratus & 0.16 & + & 0.66 & 0.15 \\
\hline Crangon septemspinosa & 6.54 & 0.16 & 1.32 & 8.84 \\
\hline Pagurus longicarpus & 1.31 & 0.18 & 1.32 & 1.96 \\
\hline Pinnixa sp. & 1.17 & 1.11 & 7.26 & 16.62 \\
\hline Cumacea & + & 0.07 & 0.66 & + \\
\hline Crab Zoea & + & + & 0.66 & + \\
\hline Neomysis americana & 1.19 & 0.33 & 10.76 & 43.30 \\
\hline Mysidacae remains & 2.50 & - & 1.32 & - \\
\hline Ampelisca abdita & 25.51 & 46.14 & 27.85 & 1996.0 \\
\hline Caprella sp. & 0.05 & 1.78 & 2.64 & 4.83 \\
\hline Corophium sp. & + & 0.15 & 1.32 & 0.17 \\
\hline Unidentified amphipods & 0.25 & 0.24 & 2.64 & 1.29 \\
\hline Teleostei (Total) & 2.67 & 0.35 & 1.98 & 5.97 \\
\hline Anchoa mitchilli & 1.60 & 0.27 & 0.66 & 1.23 \\
\hline Gobiosoma bosci & 0.10 & 0.27 & 0.66 & 0.24 \\
\hline Menidia menidia & 0.96 & + & 0.66 & 0.52 \\
\hline Hydrozoa (Total) & 16.28 & - & 7.84 & - \\
\hline Unidentified remains & 5.30 & - & 5.73 & - \\
\hline Total & 100.00 & 100.00 & & \\
\hline
\end{tabular}

\section{Diet Comparison}

The diet of winter flounder $(n=29)$ captured in Area 2 was composed mostly of polychaetes and molluscs (Table 2). The two most important species of polychaetes identified in the stomachs were Leitoscoloplos robustus and S. benedicti. Bivalve siphons were the only mollusc part to be identified, as no shell remains were found. Some decapod remains were found and the only amphipod was $A$. abdita.

Despite measured differences in the number of prey between the stomach contents of winter flounder between habitats (Fig. 3), no significant difference was found in the ranked number (Mann-
Whitney: $U=25, p \geq 0.05$ ), weight (Mann-Whitney: $U=30, p \geq 0.05$ ), or $I R I$ (Mann-Whitney: $U=29$, $p \geq 0.05$ ) of similar prey between habitats. Similar food items, by taxa, were $S$. benedicti, Pinnixa sp. and $A$. abdita but with the exception of $S$. benedicti varied in percent contribution to the diet.

\section{Benthos Analyses}

The macrobenthic habitat of Area 1 was composed of invertebrate assemblages that are indicative of opportunistic species of disturbed habitats (sensu Pearson and Rosenburg, 1978). A total of 25 species were identified from both sampling years with the numerical densites averaging $477 \pm 290 / 0.05 \mathrm{~m}^{2}$ per year. Only 3 

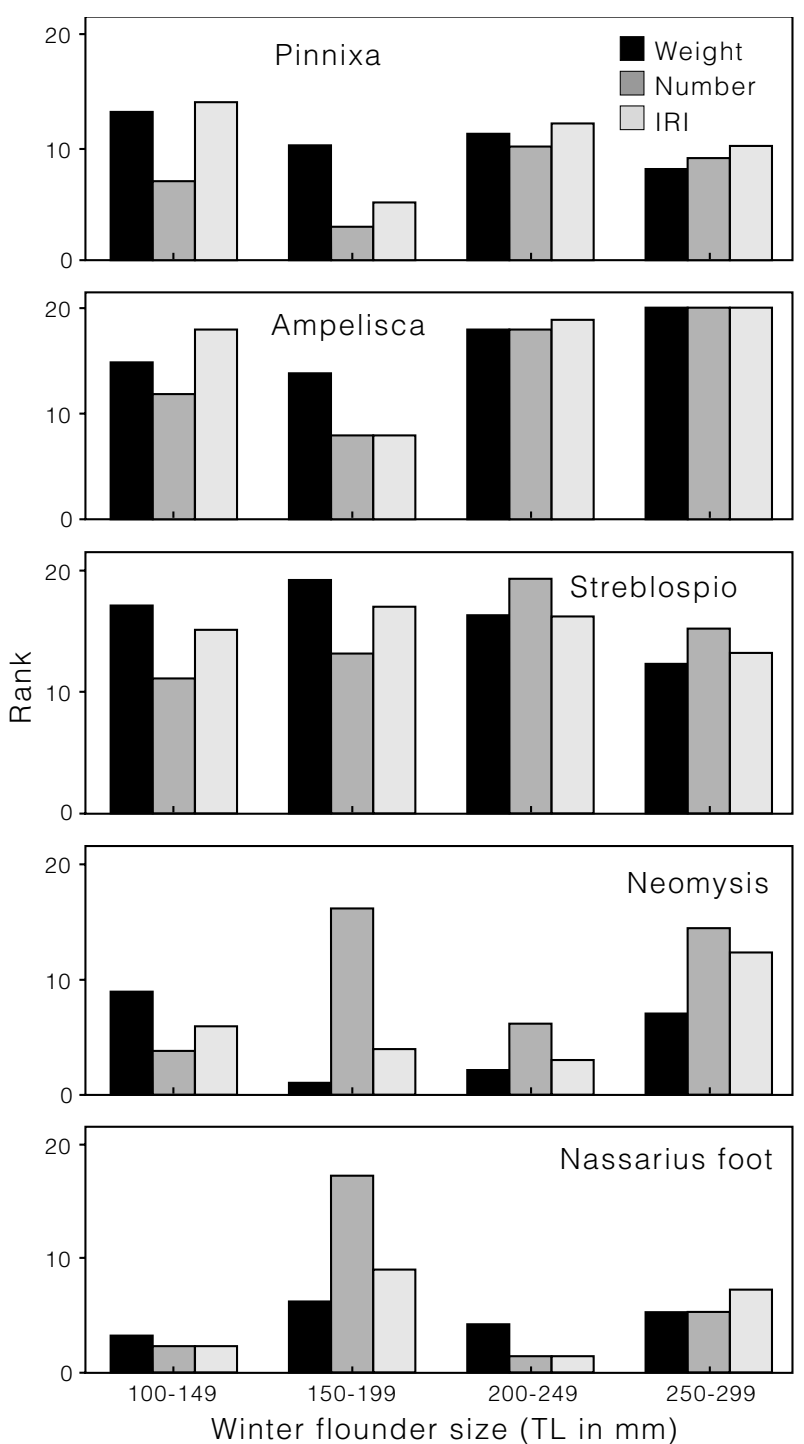

Fig. 2. Dietary comparison of the rank of principal prey items among the 4 size-classes of winter flounder captured in Area 1. Size-classes (TL) were 100$149 \mathrm{~mm}(n=32)$; $150-199 \mathrm{~mm}(n=65)$; $200-$ $249(n=31)$; and $250-300 \mathrm{~mm}(n=23)$. Principal prey are those prey items with $|R|>100$.

species numerically dominated the macrobenthos; A. abdita, and polychaetes; S. benedicti and Mediomastus ambiseta which made up $91 \%$ of the benthic community. Mulinia lateralis and Tellina agilis were the most common bivalves and represented almost $6 \%$ of the total macrobenthic community. The most abundant gastropod was Nassarius trivittatus and no decapods were sampled within the macrobenthic community.

The structure of benthic communities differed between habitats (Fig. 4). Area 2 was composed of 27 different species with numerical densities averaging $102.7 \pm 23.7 / 0.05 \mathrm{~m}^{2}$ per year. Where amphipods were the dominant taxa in the Area 1 $(54.2 \%)$, polychaetes dominated Area 2 making up $82.7 \%$ of the community followed by molluscs $(15.3 \%)$. Leitoscoloplos robustus was the most abundant organism comprising 35\% of the community. Species that were similar in abundance between habitats were limited to $S$. benedicti and T. agilis.

\section{Foraging Index}

The winter flounder in Area 1 had positive foraging indices for two macroinvertebrates. Nassarius trivitattus foot and $S$. benedicti had foraging indices of 1.2 and 0.24 , respectively. The foraging index was close to zero for Nereis succinea and $A$. abdita indicating random feeding (Table 3 ).

Some species that were abundant within the macrobenthic samples were ignored or were rarely present in stomach samples. The polychaete, M. ambiseta, numerically contributed $19.7 \%$ to the benthic community but had a negative forage index. Similarly, the bivalves $T$. agilis and $M$. lateralis were disregarded by the winter flounder but together made up almost $6 \%$ of the macrobenthic community.

The winter flounder in Area 2 had positive foraging indices for two macroinvertebrates, S. benedicti and $A$. abdita (Table 3). Random feeding was found on $L$. robustus. Similar to Area 1 some species that were abundant within the macrobenthic samples were ignored or were rarely present in stomach samples. The bivalve, Gemma gemma, and polychaetes, Eteone heteropoda, Nereis succinea, Polydora ligni, and Scolecolepides viridis, were disregarded but made up almost $25 \%$ of the macrobenthic community.

\section{Discussion}

Regardless of habitat, winter flounder fed on primarily the most abundant and active benthic species. Leitoscoloplos robustus made up the primary food for the winter flounder in the Area 2 and $S$. benedicti was important in the diets from both areas. Leitoscoloplos robustus is a subsurface deposit-feeder but is active on the sediment surface where it defecates (Bianchi, 1988). Streblospio benedicti is a surface deposit-feeder, which actively extend palps to comb the sediment surface while feeding (Gosner, 1978; Dauer, 1984). These characteristics were probably more attractive to flounder than other prey items, as winter flounder are sight feeders and are attracted to movement when searching for prey (MacDonald, 1982). In addition, most of the molluscan fragments were either gastropod foot and opercular regions or bivalve siphons with very little shell found. Winter 
TABLE 2. Diet of 29 winter flounder (size range $=50-200 \mathrm{~mm}$ TL) showing index of relative importance (IRI) of prey from Area 2 expressed in percentage weight, number and frequency of the total number of stomachs analyzed ( 0 stomachs empty). A value less than 0.05 is designated $(+)$.

\begin{tabular}{|c|c|c|c|c|}
\hline Taxon & Weight & Number & Frequency & $|R|$ \\
\hline Mollusca (Total) & 4.80 & 7.80 & 50.91 & 642.0 \\
\hline Bivalve siphons & 4.80 & 7.80 & 50.91 & 642.0 \\
\hline Polychaeta (Total) & 87.07 & 82.78 & 100.00 & 16985.00 \\
\hline Eteone heteropoda & 0.16 & 0.60 & 10.07 & 7.65 \\
\hline Leitoscoloplos robustus & 76.94 & 26.63 & 87.91 & 9104.00 \\
\hline Nereis succinea & 0.65 & 0.55 & 4.94 & 5.92 \\
\hline Glycera sp. & 1.42 & 0.06 & 2.56 & 3.78 \\
\hline Streblospio benedicti & 4.86 & 54.91 & 82.78 & 4947.00 \\
\hline Polychaeta remains & 3.04 & - & 7.14 & - \\
\hline Crustacea (Total) & 2.68 & 9.45 & 78.55 & 952.00 \\
\hline Decapod remains & 1.04 & - & 19.23 & - \\
\hline Pinnixa sp. & 0.11 & 0.11 & 2.56 & 0.56 \\
\hline Ampelisca abdita & 1.31 & 7.35 & 43.95 & 381.0 \\
\hline Edotea trilobota & 0.22 & 1.52 & 10.25 & 17.83 \\
\hline Harpacticoids & + & 0.47 & 2.56 & 1.21 \\
\hline Unidentified remains & 5.08 & - & 36.63 & - \\
\hline Total & 100.00 & 100.00 & & \\
\hline
\end{tabular}

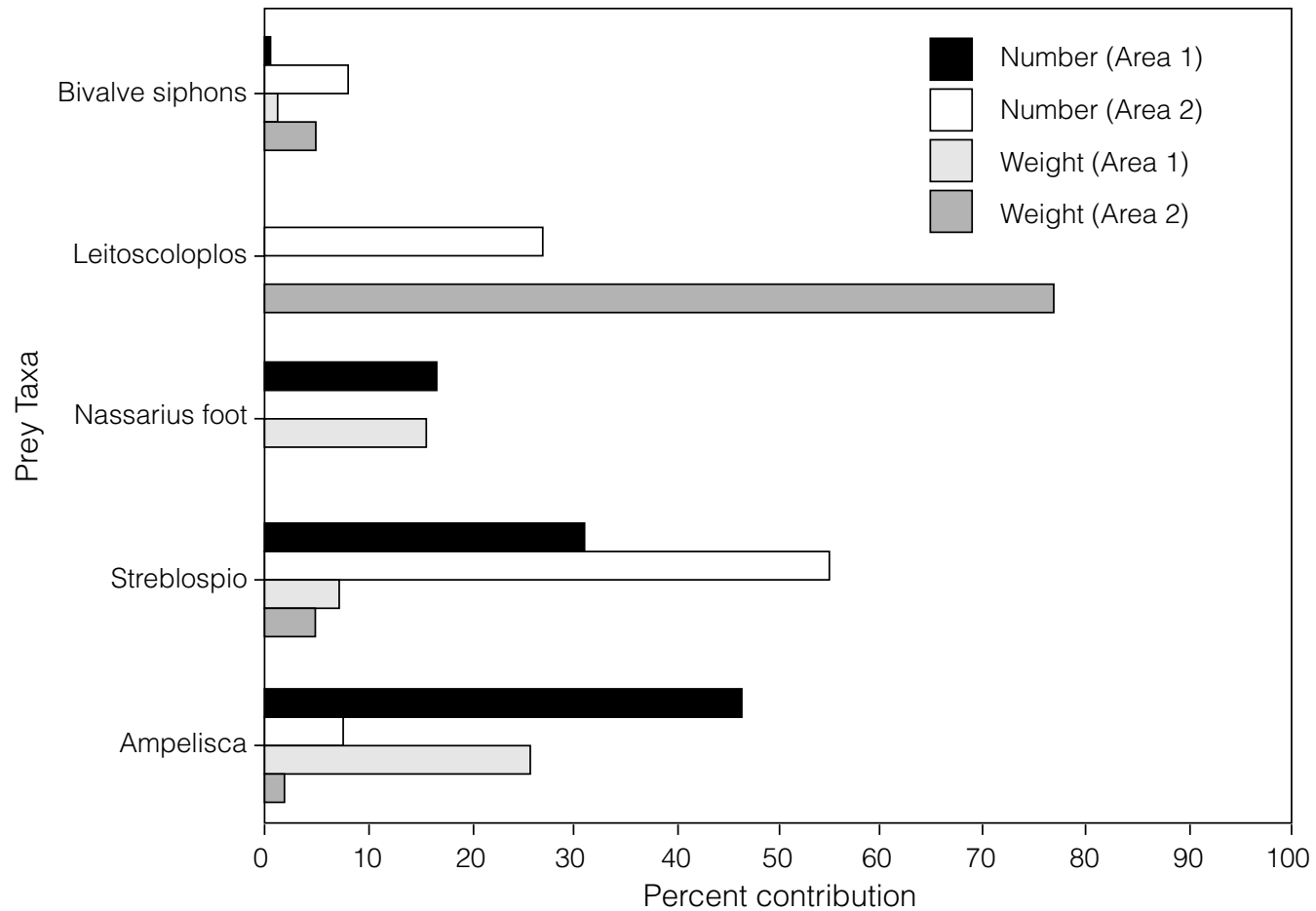

Fig. 3. Dietary comparison of the percent contribution of principal prey from New Haven Harbor (Area 1) and Clinton Harbor (Area 2). 


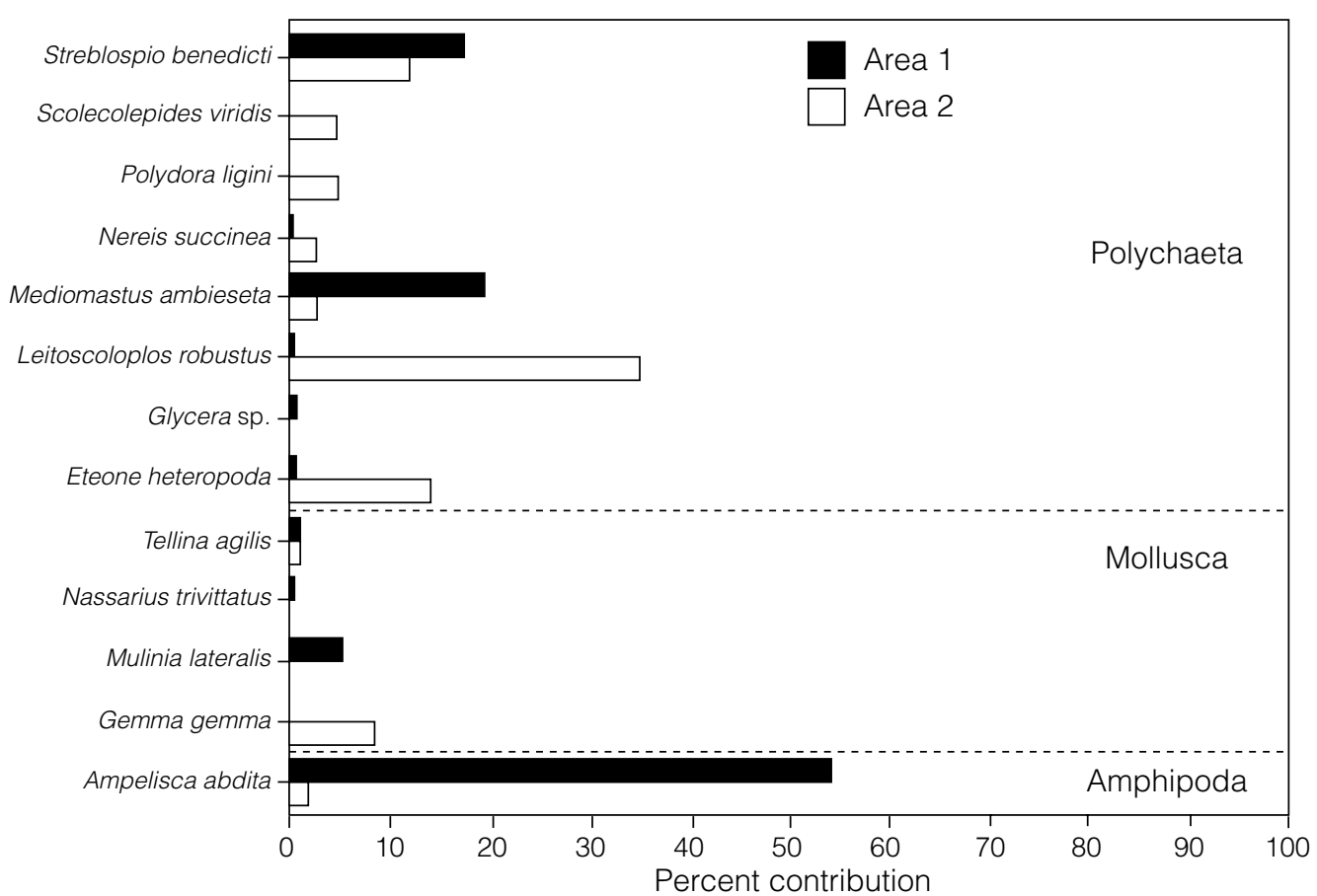

Fig. 4. A comparison of the percent contribution of the dominant macrobenthic invertebrates from New Haven Harbor (Area 1) and Clinton Harbor (Area 2).

TABLE 3. Log of Forage Index of winter flounder from macrobenthic organisms in Area 1 and Area 2, with comments on habitat and feeding mode (from Gosner, 1978).

\begin{tabular}{|c|c|c|c|c|}
\hline Genera & Habitat & Feeding mode & $\begin{array}{l}\text { Forage } \\
\text { Index } \\
\text { Area } 1\end{array}$ & $\begin{array}{c}\text { Forage } \\
\text { Index } \\
\text { Area } 2\end{array}$ \\
\hline Ampelisca & epifaunal & Filter feeder & -0.07 & 0.69 \\
\hline Eteone & infaunal & Predator & -0.50 & -1.37 \\
\hline Gemma & infaunal & Filter feeder & a & $\infty$ \\
\hline Glycera & infaunal & Predator & $\infty$ & a \\
\hline Illynassa & epifaunal & Surface deposit & a & a \\
\hline Leitoscoloplos & infaunal & Subsurface deposit & a & -0.13 \\
\hline Mediomastus & infaunal & Subsurface deposit & -2.62 & $\infty$ \\
\hline Mulinia & infaunal & Filter feeder & $\infty$ & $\infty$ \\
\hline Nassarius & epifaunal & Surface deposit & 1.2 & a \\
\hline Nereis & epifaunal & Surface deposit & -0.01 & -0.78 \\
\hline Polydora & infaunal & Surface deposit & a & $\infty$ \\
\hline Scolecolepides & infaunal & Surface deposit & a & $\infty$ \\
\hline Spio & infaunal & Surface deposit & a & $\infty$ \\
\hline Streblospio & infaunal & Surface deposit & 0.24 & 0.66 \\
\hline Tellina & infaunal & Subsurface deposit & $\infty$ & $\infty$ \\
\hline
\end{tabular}

a Not present in benthic habitat.

flounder probably nipped off these body regions as these were the most exposed and active parts of the body.

Although relatively abundant in the macrobenthos of both habitats, M. ambiseta,
G. gemma and T. agilis were ignored or avoided as prey items by winter flounder most likely due to differences in spatial distributions and behaviour. Gemma gemma and T. agilis are small infaunal clams and avoid predation by burrowing within the sediment (Pihl et al., 1992). Steimle et al. (1993) 
suggested the nut clam, Nucula proxima, avoided predation from winter flounder because of its infaunal habitats. Similarly, M. ambiseta is a burrowing, subsurface deposit feeding polychaete (Gaston and Nasci, 1988), so it is not as active at the sediment-water interface as species like $S$. benedicti or L. robustus.

Although there was some similarity in species composition, the overall structure of benthic communities differed between habitats. Area 1 had a higher density with fewer different species and was numerically dominated by $A$. abdita whereas Area 2 was dominated by L. robustus. Furthermore, species in highest abundance in Area 2 like L. robustus, is a later successional stage polychaete (Rhoads, 1974). Opportunistic species, like $S$. benedicti, that were found in Area 2 was likely due to the mild natural disturbance that occurs in intertidal habitats from exposure on ebb tides (Levinton, 1982).

Similar to other studies on fish diets, ampeliscan amphipods are important food sources. Collie (1987) found ampeliscans to be an important dietary component of yellowtail flounder (Limanda ferruginea) off southern Nantucket, Massachussetts, USA. Franz and Tanacredi (1992) report $A$. abdita made up $88 \%$ of the diet in winter flounder in the anthropogenically disturbed habitat of Jamaica Bay, New York, USA. Kaiser and Spencer (1994) determined gurnards (Aspitrigila cuculus), lesser spotted dogfish (Scyliorhinus canicula) and whiting (Merlangius merlangus) migrated into beam trawl scavenged areas to feed on Ampelisca spinipes. Ampeliscans, in particular A. abdita, are a tubedwelling amphipod occurring in dense population on the sediment surface in habitats where recent or chronic anthropogenic disturbance has occurred (Rhoads et al., 1978).

Ampelisca abdita is presumably less active on the sediment surface except for movement by ventral appendages for water circulation. The dense population of these amphipods and probable low search and handling time apparently account for its extreme importance in the diet of flounder from Area 1. However, the importance $(|R|=381)$ of A. abdita in the diet of flounder from Area 2 could not be explained, where these invertebrates were in low abundance. Although young-of-year winter flounder are limited in movement (Saucerman and Deegan, 1991), it is possible that older fish undertake some daily migration and may forage for these prey items in adjacent habitats where they are in higher abundance. The positive foraging index calculated for flounder in Area 2 may provide some evidence for this.
The continual human disturbance to Area 1 allows for the dominance of $A$. abdita. A macrobenthic monitoring study by Pellegrino (1990) reported the dominance of $A$. abdita in New Haven Harbor during June, August and October from 1988-90 throughout the same general area as this study. Furthermore, the highest secondary production in New Haven Harbor was in areas dominated by $A$. abdita and the presence of these species may enhance the community (Pellegrino, 1990). However, a change in environmental conditions favourable to these species could impact the energy structure and value of the community to winter flounder. Franz and Tanacredi (1992) suggested a decrease in the population density of A. abdita in Jamaica Bay, New York, USA could significantly reduce the value of the habitat as a nursery area for winter flounder.

This study supports the contention that winter flounder are in general, opportunistic feeders and usually feed on the most abundant and available prey source. They do, however, seem to select certain prey items such as $A$. abdita and this may be advantageous to the population. The high secondary production by $A$. abdita, density, and importance to all sizes of the winter flounder may improve stocks of winter flounder in New Haven Harbor as was found in other habitats (Franz and Tanacredi, 1992). However, since winter flounder production has not been quantified in New Haven Harbor, future study should be focused on production to biomass of winter flounder with A. abdita and other prey items.

\section{Acknowledgements}

Dr. P. E. Pellegrino of Southern Connecticut State University provided guidance throughout this study. We thank S. Cappella and L. Green for their assistance in the collection and gut analysis of the winter flounder. B. Baca of the University of Mississippi provided help with statistics. We are also grateful to Capt. Michael Primer for his reliable operation of the Suzi II.

\section{References}

BECKER, S. D., and K. K. CHEW. 1987. Predation on Capitella sp. by small mouth pleuronectids in Puget Sound, Washington. Fish. Bull., 85: 471-479.

BIANCHI, T. S. 1988. Feeding ecology of subsurface deposit-feeder Leitoscoloplos fragilis Verril. I. Mechanisms affecting particle availability on intertidal sandflat. J. Exp. Mar. Biol. Ecol., 115: 79-97.

COLLIE, J. S. 1987. Food consumption by yellowtail flounder in relation to production of its benthic prey. Mar. Ecol. Prog. Ser., 36: 205-213. 
DAUER, D. M. 1984. Functional morphology and feeding behaviour of Streblospio benedicti (Polychaeta: Spionidae). In: Proceedings of the First International Polychaete Conference, Sydney, Australia. P. A. Hutchings (ed.). The Linnean Society of New South Wales, p. 418-429.

FRAME, D. W. MS 1972. Biology of young winter flounder Pseudopleuronectes americanus (Walbaum): feeding habits, metabolism and food utilization. Ph.D. thesis. Univ. Massachussetts, Amherst.

FRANZ, D R., and J. T. TANACREDI. 1992. Secondary production of the amphipod Ampelisca abdita and its importance in the diet of juvenile winter flounder (Pleuronectes americanus) in Jamaica Bay, New York. Estuaries, 15: 193-203.

GOSNER, K. L. 1978. A field guide to the Atlantic seashore. Houghton Mifflin Company, Boston, MA, $329 \mathrm{p}$

GASTON, G. R., and J. C. NASCI. 1988. Trophic structure of macrobenthic communities in the Calcasieu estuary, Louisiana. Estuaries, 11(3): 201-211.

GRONLUND, W. D., S. L. CHAN, B. B. MCCAIN, R. C. CLARK, M. S. MYERS, J. E. STEIN, D. W. BROWN, J. T. LANDAHL, M. M. KRAHN, and U. VARANASI. 1991. Multidisciplinary assessment of pollution at three sites in Long Island Sound. Estuaries, 14: 299-305.

HACUNDA, J. S. 1981. Trophic relationships among demersal fishes in a coastal area of the Gulf of Maine. Fish. Bull., 79: 775-788.

HOWELL, P., and D. SIMPSON. 1994. Abundance of marine resources in relation to dissolved oxygen in Long Island Sound. Estuaries, 17(2): 394-402.

JACOBS, J. 1974. Quantitative measurements of food selection: a modification of the forage ratio and Ivlev's electivity index. Oecol., 14: 413-417.

KAISER, M. J., and B. E. SPENCER. 1994. Fish scavenging behaviour in recently trawled areas. Mar. Ecol. Prog. Ser., 112: 41-49.

KEATS, D. W. 1990. Food of winter flounder (Pseudopleuronectes americanus), in a sea urchin dominated community in eastern Newfoundland. Mar. Ecol. Prog. Ser., 60: 13-22.

KLEIN-MACPHEE, G. MS 1978. Synopsis of the biological data for the winter flounder, Pseudopleuronectes americanus (Walbaum). NOAA Technical Report. NMFS Circ. 414, FAO Fish. Synopsis 117. Washington, D.C., $43 \mathrm{p}$.

LEVINTON, J. S. 1982. Marine Ecology. Prentice-Hall, Inc. N.J., $526 \mathrm{p}$.

MACDONALD, J. S. 1982. Laboratory observations of the feeding behaviour of ocean pout and winter flounder with reference to niche overlap of natural populations. Can. J. Zool., 61: 539-545.

MACDONALD, J. S., and R. H. GREEN. 1986. Food resource utilization by five species of benthic feeding fish in Passamaquoddy Bay, New Brunswick. Can. J. Fish. Aquat. Sci., 39: 1534-1546.

MCMANUS, J. W., and D. PAULY. 1990. Measuring ecological stress: variations on a theme by $R$. M. Warwick. Mar. Biol., 106: 305-308.

MROCZKA, M. E. MS 1991. An investigation of the finfish utilization of a coastal marina basin with special emphasis on the winter flounder, Pseudopleuronectes americanus (Walbaum). M. S. Thesis. Southern Connecticut State University, $86 \mathrm{p}$.

PEARCY, W. G. 1962. Ecology of an estuarine population of winter flounder, Pseudopleuronectes americanus (Walbaum). Bull. Bingham. Oceanogr. Coll., 18(1): $1-78$.

PEARSON, T. H., and R. ROSENBERG. 1978. Macrobenthic succession in relation to organic enrichment and pollution of the marine environment. Oceanogr. Mar. Biol. Annu. Rev., 16: 229-311.

PELLEGRINO, P. E. 1990. Macrobenthic Monitoring Program of New Haven Harbor: structure and functional analyses. Final report to United Illuminating, New Haven, CT, 112 p.

PIANKA, L. S., M. S. OLIPHANT, and I. L. K. IVERSON. 1971. Food habitats of albacore, bluefin tuna, and bonito in California waters. Calif. Dep. Fish Game. Bull., 152, $105 \mathrm{p}$.

PIHL, L., S. P. BADEN, R. J. DIAZ, and L. C. SCHAFFNER. 1992. Hypoxia-induced structural changes in the diet of bottom feeding fish and Crustacea. Mar. Biol., 112: 349-361.

RAND, M. C., A. E. GREENBURG, and M. J. TARAS. 1975. Standard methods for examination of water and waste water. American Public Health Association, Washington, D.C., 1193 p.

RHOADS, D. C. 1974. Organism-sediment relationships on the muddy sea floor. Oceanogr. Mar. Biol. Annu. Rev., 12: 263-300.

RHOADS, D. C., P. L. MCCALL, and J. Y. YINGST. 1978. Disturbance and production on the estuarine seafloor. Am. Sci., 66: 577-586.

RICHARDS, S. W. 1963. The demersal fish population of Long Island Sound. Bull. Bingham. Oceanogr. Coll., 18(2): 1-101.

ROBERTSON, A. B., B. W. GOTTHOLM. D. D. TURGEON, and D. A. WOLFE. 1991. A comparative study of contaminant levels in Long Island Sound. Estuaries, 14: 290-298.

SAUCERMAN, S. E., and L. A. DEEGAN. 1991. Lateral and cross-channel movements of young-of-the-year winter flounder (Pseudopleuronectes americanus) in Waquoit Bay, Massachusetts. Estuaries, 14: 440-446.

SMITH, E. M., E. C. MARIANI, A. P. PETRILLO, L A. GUNN, and M. S. ALEXANDER. 1989. Principal fisheries of Long Island Sound, 1961-1985. Connecticut Department of Environmental Protection. Mar. Fish. Program, $47 \mathrm{p}$.

STEIMLE, F. W., D. JEFFRESS, S. A. FROMM, R. N. REID, J. J. VITALIANO, and A. FRAME. 1993. Predator-prey relationships of winter flounder, Pleuronectes americanus, in the New York bight apex. Fish. Bull., 92: 608-619.

TUBMAN, M. 1979. Hydrography of New Haven Harbor and physical/chemical effects from operation of United Illuminating. In: Station Report for United Illuminating, New Haven.

TYLER, A. V. 1972. Food resource division among northern, marine, demersal fishes. J. Fish. Res. Board Can., 29: 997-1003.

WARWICK, R. M. 1986. A new method for detecting pollution effects on marine macrobenthic communities. Mar. Biol., 92: 557-562.

WOlFE, D. A., A. R. MONAHAN, P. E. STACEY, D. R. G. FARROW, and A. ROBERTSON. 1991. Environmental quality of Long Island Sound: assessment and management issues. Estuaries, 14: 224-236.

ZAR, J. H. 1984. Biostatistical analysis. Prentice-Hall. Englewood Cliffs. 718 p. 
Blank 